\title{
Perbedaan Hasil Belajar Siswa yang Diajar Menggunakan Strategi Pembelajaran Aktif Tipe Index Card Match dengan Card Sort pada Materi Sistem Ekskresi Manusia di SMA Negeri 1 Binjai
}

\author{
The Difference of Students' Learning Outcomes Using Active Learning Strategy Index Card Match with Card \\ Sort on Human Excretory System Topic In Natural Sciences Students SMA Negeri 1 Binjai \\ Diana Puspita* dan Puji Prastowo \\ Program Studi Pendidikan Biologi, FMIPA, Universitas Negeri Medan, \\ Jl. Willem Iskandar Psr. V Medan Estate \\ Fax. (061) 614002-613319, Medan, Indonesia, 20221 \\ *E-mail : dianapuspita2601@gmail.com
}

\begin{abstract}
Abstrak
Penelitian ini bertujuan untuk mengetahui perbedaan hasil belajar siswa yang diajar menggunakan strategi pembelajaran aktif tipe Index Card Match dengan Card Sort pada materi sistem ekskresi manusia di kelas XI IPA SMA Negeri 1 Binjai Kabupaten Langkat tahun pembelajaran 2015/2016. Jenis penelitian ini adalah eksperimen semu dan rancangan penelitian yang digunakan adalah "Only Post-test Group Design". Populasi penelitian yaitu seluruh siswa kelas XI IPA. Sampel penelitian diambil secara random sampling (sampel acak) yang berjumlah 86 orang terdiri dari 2 kelas. Kelas XI IPA 3 diajar menggunakan strategi pembelajaran aktif tipe Index Card Match dan kelas XI IPA 2 diajar menggunakan strategi pembelajaran aktif tipe Card Sort. Hasil penelitian menunjukkan bahwa hasil belajar siswa yang diajar menggunakan Index Card Match $(81,04 \pm 9,42)$ lebih tinggi dari hasil belajar siswa yang diajar dengan Card Sort $(75,81 \pm 9,99)$. Hipotesis menggunakan uji $t$ menunjukkan bahwa hasil tersebut berbeda secara signifikan pada taraf kepercayaan $\alpha=0,05$.
\end{abstract}

Kata Kunci: Hasil Belajar Siswa, Index Card Match, Card Sort

\begin{abstract}
This research aim to determine the difference of students' learning outcomes are taught by active learning strategy Index Card Match with Card Sort type on human excretory system topic in class XI IPA SMA Negeri 1 Binjai Kabupaten Langkat academic year 2015/2016. The type of this research was quasy experimental and used "Only Post-test Group Design". The population were all the students of class XI IPA. The sample of this research were taken by random sampling technique that the total number of students are 86 students that consists of 2 classes. Class XI IPA 3 was taught by active learning strategy Index Card Match type and class XI IPA 2 was taught by active learning strategy Card Sort type. The result of this research showed the average of students' learning outcome were taught by active learning strategy Index Card Match $(81,04 \pm 9,42)$ type is higher than the average of students' learning outcome were taught by Card Sort type $(75,81 \pm 9,99)$. Hypothesis test used t test showed that the result was significantly different at the level of confidence $\alpha=0,05$.
\end{abstract}

Keywords: Students' Learning Outcomes, Index Card Match, Card Sort

\section{PENDAHULUAN}

Kegiatan belajar mengajar pada dasarnya merupakan pemberian stimulus-stimulus kepada siswa, agar terjadinya respons yang positif pada diri siswa. Kesediaan dan kesiapan siswa dalam mengikuti proses demi proses dalam pembelajaran akan mampu menimbulkan respons yang baik terhadap stimulus yang siswa terima dalam proses pembelajaran. Interaksi antara guru dan siswa pada saat proses belajar mengajar berlangsung memegang peranan penting untuk mencapai tujuan yang diinginkan.
Banyak faktor yang mempengaruhi keberhasilan siswa dalam belajar baik dari dalam diri siswa (internal) maupun dari luar diri siswa (eksternal). Salah satu faktor yang berasal dari dalam diri siswa adalah aktivitas siswa. Salah satu faktor eksternal bersumber dari guru adalah kurangnya pengadaan variasi dalam proses pembelajaran (Dimyati, dkk., 2013).

Pendukung peningkatan program pembelajaran berkualitas di sekolah adalah peningkatan kualitas pendidikan yang banyak diperankan oleh guru, karena guru adalah praktisi, 
teoritis dengan langkah-langkah inovatif yang sangat menentukan dalam mengelola kelas. Tugas pendidik adalah menemukan, menggugah dan mempertahankan motivasi siswa untuk belajar. Motivasi siswa dalam pembelajaran akan memengaruhi hasil belajar.

Berdasarkan pengamatan penulis pada saat melakukan kegiatan Program Pengalaman Lapangan Terpadu (PPLT), umumnya guru biologi dalam menyampaikan pembelajaran masih menggunakan strategi pembelajaran konvensional seperti ceramah, penugasan, dan diskusi. Pendapat Marjan dkk (2014) menyatakan bahwa "pembelajaran konvensional sudah tidak begitu efektif untuk digunakan dalam pembelajaran sekarang, terlihat dari sebagian siswa tidak memahami materi sehingga tujuan yang diinginkan sekolah tidak tercapai". Sementara menurut wawancara penulis dengan seorang guru biologi, kurangnya interaksi antara guru dan siswa dan tidak melibatkan siswa secara aktif dalam setiap kegiatan pembelajaran menyebabkan hasil belajar biologi yang dicapai kurang optimal. Hal tersebut dapat terlihat dari hasil observasi penulis bahwa persentase siswa yang mencapai KKM (Kriteria Ketuntasan Minimimal) untuk mata pelajaran biologi kelas XI IPA SMA Negeri 1 Binjai Kabupaten Langkat yang ditetapkan dengan nilai 78 , hanyalah sebesar 59\% (data terlampir). Motivasi belajar biologi siswa masih rendah karena beberapa siswa menganggap materi biologi identik dengan hapalan.

Salah satu solusi untuk melihat hasil belajar siswa serta proses pembelajaran adalah dengan mengkondisikan siswa untuk dapat belajar secara aktif dengan saling berbagi informasi dengan temannya. Kondisi-kondisi tersebut dapat diciptakan dengan menerapkan strategi pembelajaran aktif dalam pembelajaran biologi. Strategi pembelajaran aktif yaitu pembelajaran yang menerapkan siswa sebagian besar melakukan aktivitas belajar. Strategi pembelajaran aktif juga merupakan salah satu cara penyajian materi yang dapat meningkatkan motivasi siswa dalam belajar.

Strategi pembelajaran aktif tipe Index Card Match (mencari pasangan kartu) adalah suatu strategi pembelajaran yang mengajak siswa untuk belajar aktif dan bertujuan agar siswa mempunyai jiwa kemandirian dalam belajar serta menumbuhkan daya kreatifitas. Strategi pembelajaran aktif tipe Index Card Match cocok diterapkan pada siswa SMA karena strategi ini mengikutsertakan siswa secara aktif, mengandung unsur permainan sehingga diharapkan siswa tidak bosan dalam belajar biologi. Selain itu, strategi ini mempunyai peranan penting memberikan efek yang menyenangkan yaitu mampu memberi kesan yang mendalam pada siswa sehingga akan mempermudah dan meningkatkan motivasi belajar untuk belajar lebih rajin serta memperoleh hasil belajar biologi yang optimal.

Selain strategi pembelajaran aktif tipe Index Card Match, ada juga strategi pembelajaran aktif tipe Card Sort (memilih kartu/menyortir kartu). Strategi pembelajaran aktif tipe Card Sort merupakan kegiatan kolaboratif yang bisa digunakan untuk mengajarkan konsep, penggolongan sifat, fakta tentang suatu objek atau mengulang informasi. Strategi pembelajaran aktif tipe ini menekankan pada kerjasama kelompok yang dapat melibatkan peran siswa secara menyeluruh sehingga dapat membantu menghilangkan kejenuhan selama pembelajaran. Tujuan dari kegiatan Card Sort yaitu untuk untuk mengungkapkan daya ingat (recall) terhadap materi pelajaran yang telah dipelajari siswa.

Materi sistem ekskresi manusia merupakan salah satu materi pelajaran biologi yang dipelajari di SMA. Menurut Hanifah yang dikutip Achmad dkk. (2014) bahwa materi sistem ekskresi pada manusia merupakan materi yang bersifat konkret tetapi untuk prosesnya tidak dapat diinderai, karena kajiannya yang mencakup poses fisiologi yang terjadi didalam tubuh manusia. Sistem ekskresi merupakan salah satu konsep yang cukup sulit karena banyak unsur hafalan, terlalu banyak istilah, dan beberapa faktor lainnya. Materi ini berhubungan dengan konsep-konsep yang membutuhkan pemahaman mendalam dan ingatan yang kuat tentang alat-alat ekskresi dan bagian-bagiannya serta proses-proses yang terjadi pada alat-alat ekskresi tersebut seperti proses pengeluaran urin, ekskresi cairan empedu oleh hati, pengeluaran karbondioksida oleh paru-paru, dan proses pengeluaran keringat oleh kulit. Selain itu dalam materi ini juga banyak menggunakan 
bahasa latin sehingga perlu dilakukan suatu strategi yang bisa membuat siswa belajar sambil mengingat. Materi ini perlu diajarkan di sekolah dengan pembelajaran yang berkualitas supaya siswa tidak hanya mampu memahami tentang alatalat ekskresi beserta prosesnya, tetapi juga mampu mengingatnya agar dapat menerapkan dalam kehidupan sehari-hari. Apabila pada materi ini siswa diajar dengan strategi pembelajaran aktif, diharapkan hasil belajar siswa menjadi optimal. Untuk itu, dapat digunakan strategi pembelajaran aktif tipe Index Card Match dan Card Sort supaya motivasi belajar siswa meningkat dan siswa mampu mengoptimalkan daya ingat terhadap materi ini.

Sukmawati (2014) menemukan bahwa pembelajaran menggunakan strategi pembelajaran aktif tipe Index Card Match dapat meningkatkan hasil belajar siswa menjadi lebih baik pada materi pokok bahasan jaringan hewan. Sementara itu hasil penelitian tindakan kelas yang dilakukan oleh Mufidah, dkk. (2013) menyimpulkan bahwa penerapan strategi pembelajaran Card Sort dapat meningkatkan hasil belajar IPA materi cahaya dan sifat-sifatnya pada siswa kelas V SD Negeri 01 Ngasem, Colomadu tahun ajaran 2012/2013. Haryanto (2011) juga mengemukakan bahwa ada perbedaan prestasi belajar antara siswa yang mendapatkan pembelajaran menggunakan strategi pembelajaran aktif tipe Index Card Match dan Card Sort pada pokok bahasan getaran dan gelombang siswa kelas VIII MTs. Futuhiyyah 1 Mrangen Demak.

Berdasarkan beberapa hasil penelitian tersebut, penulis tertarik untuk melakukan penelitian tentang "Perbedaan Hasil Belajar Siswa yang Diajar Menggunakan Strategi Pembelajaran Aktif Tipe Index Card Match dengan Card Sort pada Materi Sistem Ekskresi Manusia di Kelas XI IPA SMA Negeri 1 Binjai Kabupaten Langkat Tahun Pembelajaran 2015/2016." Penggunaan strategi pembelajaran aktif tipe Index Card Match dan Card Sort diharapkan dapat mengaktifkan siswa dalam proses pembelajaran biologi, meningkatkan pemahaman siswa dalam materi sistem ekskresi manusia sehingga mampu mengaktifkan siswa dalam proses pembelajaran dan dapat meningkatkan hasil belajar biologi. Penelitian ini bertujuan untuk mengetahui ada tidaknya perbedaan hasil belajar biologi siswa yang diajar menggunakan strategi pembelajaran aktif tipe Index Card Match dengan Card Sort pada materi sistem ekskresi manusia di kelas XI IPA SMA Negeri 1 Binjai Kabupaten Langkat tahun pembelajaran 2015/2016.

\section{METODE PENELITIAN}

Lokasi Penelitian ini dilaksanakan di SMA Negeri 1 Binjai Kabupaten Langkat yang terletak di Jalan Yos Sudarso Desa Sukamakmur Kecamatan Binjai dan waktu penelitian pada bulan Maret-April 2016. Populasi penelitian adalah seluruh siswa kelas XI IPA SMA Negeri 1 Binjai Kabupaten Langkat yang terdiri dari tiga kelas, dengan jumlah 129 orang siswa. Sampel penelitian ini diambil sebanyak 2 kelas XI IPA SMA Negeri 1 Binjai Kabupaten Langkat. Dimana teknik pengambilan sampel dengan cara random sampling yaitu kelas Eksperimen I diajar menggunakan strategi Index Card Match dengan jumlah siswa sebanyak 43 orang dan kelas eksperimen II diajar menggunakan strategi Card Sort dengan jumlah siswa 43 orang. Jadi total sampel sebanyak 86 orang siswa.

Jenis penelitian ini adalah penelitian eksperimen semu. Jenis data yang digunakan adalah jenis data kuantitatif, yaitu data tentang hasil belajar siswa didapatkan dari hasil pengisian tes akhir (postes). Tes akhir penelitian memuat pertanyaan-pertanyaan yang berkaitan dengan materi yang telah diajarkan. Tes yang diberikan adalah tes tertutup yaitu kemungkinan jawaban sudah ditentukan terlebih dahulu dan responden tidak diberi kesempatan untuk memberikan jawaban lain. Angket analisis faktor kesulitan belajar ini diberikan dengan tipe pilihan ganda. Tes hasil belajar terdiri dari 20 item yang disusun dengan bentuk pilihan berganda. Tes ini diberikan kepada siswa dan siswa tinggal memilih dari lima option pilihan jawaban yang telah disediakan. Soal yang dijawab benar diberi skor 1 dan jika salah diberi skor 0 . Untuk melihat kelayakan instrumen penelitian dilakukan uji kelayakan data berupa uji validitas tes, uji reliabilitas tes, uji indeks (tingkat) kesukaran soal, dan uji daya beda (indeks diskriminan) tes. 
Teknik analisis yang digunakan adalah teknik analisis kuantitatif, ada 3 langkah yang digunakan untuk menganalisis hasil penelitian, yaitu: uji kelayakan data, analisis data, dan uji hipotesis. Pada tahap uji kelayakan data yang dilakukan adalah: (1) menguji homogenitas varians skor antara kelas eksperimen 1 dan eksperimen 2; (2) melakukan uji normalitas untuk mengetahui apakah data berdistribusi normal atau tidak menggunakan uji Lilliefors. Pada tahap analisis data yang harus dilakukan adalah: (1) menghitung nilai hasil belajar lalu menetapkan kriteria penggolongan hasil belajar menurut Usman (2005) dimana nilai 90-100 termasuk kategori sangat tinggi, 80-89 termasuk kategori tinggi, 70-79 termasuk kategiori sedang, 60-69 termasuk kategori rendah, dan $\leq 59$ termasuk kategori sangat rendah; (2) menghitung nilai rata-rata (mean) kedua kelas; (3) menghitung standar deviasi dan varians. Pada uji hipotesis, kriteria pengujiannya adalah : $\mathrm{H}_{\mathrm{o}}$ diterima jika $-t_{\text {tabel }}<$ $t_{\text {hitung }}<t_{\text {tabel }}$ pada taraf signifikan $\alpha=0,05 . \mathrm{H}_{\circ}$ ditolak jika $-t_{\text {hitung }}<-t_{\text {tabel }}$ atau $t_{\text {hitung }}>t_{\text {tabel }}$ pada taraf signifikan $\alpha=0,05$.

\section{HASIL PENELITIAN}

Berdasarkan hasil penelitian diperoleh bahwa nilai rata-rata hasil belajar siswa pada kelas Index Card Match sebesar 81,04 dengan simpangan baku (SD) sebesar 9,42. Nilai tertinggi pada kelas Index Card Match yaitu 95 sebanyak 5 orang $(11,63 \%)$, nilai terendah yaitu 55 sebanyak 1 orang $(2,32 \%)$, dan nilai dengan frekuensi tertinggi yaitu 80 sebanyak 17 orang (39,53\%). Sementara pada kelas Card Sort diketahui nilai rata-rata hasil belajar siswa sebesar 75,81 dengan simpangan baku (SD) sebesar 9,99. Nilai tertinggi pada kelas Card Sort yaitu 95 sebanyak 1 orang (2,32\%), nilai terendah yaitu 55 sebanyak 4 orang $(9,30 \%)$ dan nilai dengan frekuensi tertinggi yaitu 80 sebanyak 15 orang $(34,88 \%)$.

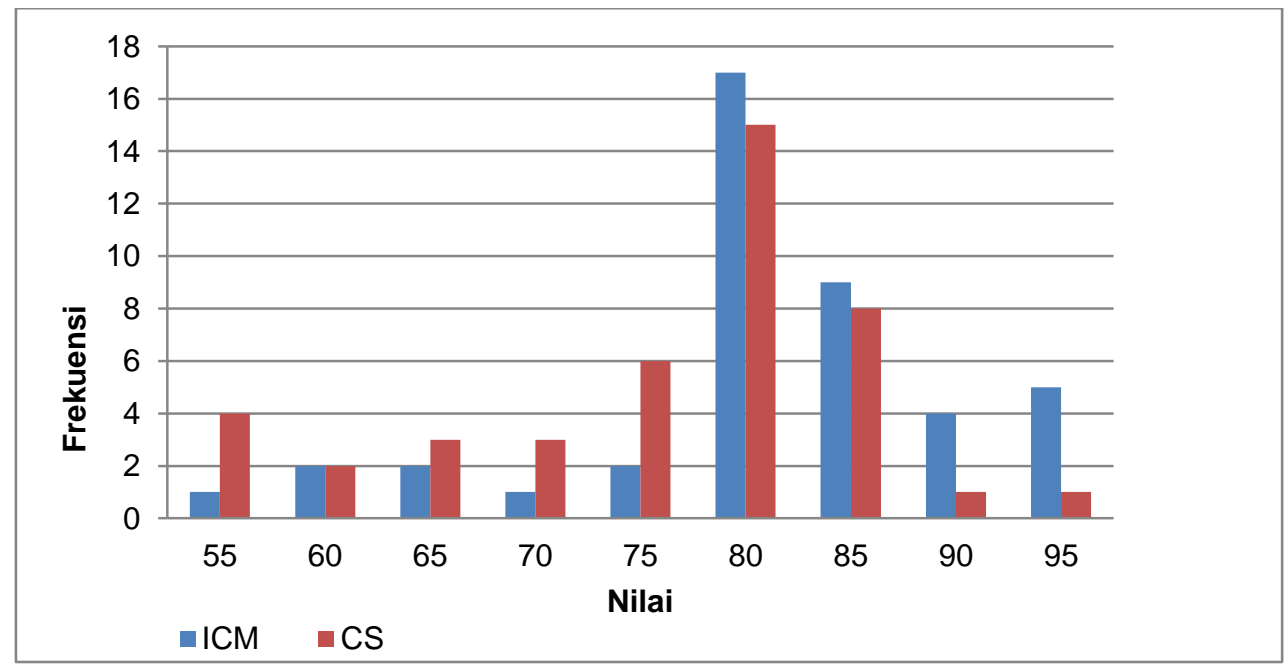

Gambar 1. Perbedaan Nilai Hasil Belajar Siswa di Kelas Index Card Match (ICM) dan Card Sort (CS)

Tabel 1. Kriteria Pencapaian Kognitif Siswa

\begin{tabular}{cccccc}
\hline \multirow{2}{*}{ Nilai } & \multirow{2}{*}{ Kategori } & \multicolumn{2}{c}{ Frekuensi Index Card Match } & \multicolumn{2}{c}{ Frekuensi Card Sort } \\
\cline { 3 - 6 } & & Absolut & Relatif (\%) & Absolut & Relatif (\%) \\
\hline $90-100$ & Sangat tinggi & 9 & 20,93 & 2 & 4,65 \\
$80-89$ & Tinggi & 26 & 60,46 & 23 & 53,48 \\
$70-79$ & Sedang & 3 & 6,98 & 9 & 20,93 \\
$60-69$ & Rendah & 4 & 9,30 & 5 & 11,62 \\
$\leq 59$ & Sangat Rendah & 1 & 2,32 & 4 & 9,30 \\
\hline
\end{tabular}


Uji normalitas data hasil belajar kelas yang menggunakan strategi pembelajaran aktif tipe Index Card Match diperoleh $\mathrm{L}$ hitung $(0,131)<\mathrm{L}$ tabel $(0,136)$ dan data hasil belajar kelas yang menggunakan strategi pembelajaran aktif tipe Card Sort $\mathrm{L}$ hitung $(0,134)<\mathrm{L}$ tabel $(0,136)$ pada taraf nyata $\alpha=0,05$. Dengan demikian dapat disimpulkan bahwa data pada kelompok sampel berdistribusi normal. Hasil perhitungan uji homogenitas untuk data hasil belajar diuji kesamaan variansnya dan diperoleh $F_{\text {hitung }}=1,12$ sedangkan $F_{\text {tabel }}=1,67$, sehingga diperoleh $F_{\text {hitung }}$
$(1,12)<F_{\text {tabel }}(1,67)$ yang berarti data hasil belajar memiliki varians yang homogen.

Berdasarkan tabel hasil perhitungan uji-t, diperoleh $t_{\text {hitung }}$ sebesar 2,49 sedangkan $t_{\text {tabel }}(d k=$ 84) pada taraf $\alpha=0,05$ adalah 1,98 . Hal ini berarti $t_{\text {hitung }}$ lebih besar dari $t_{\text {tabel }}$ atau $t_{\text {hitung }}>t_{\text {tabel }}(2,49>$ 1,98). Dengan demikian, dapat diinterpretasikan bahwa terdapat perbedaaan yang signifikan hasil belajar biologi siswa kelas XI IPA SMA Negeri 1 Binjai Kabupaten Langkat yang diajar dengan strategi pembelajaran aktif tipe Index Card Match dengan yang diajar dengan strategi pembelajaran aktif tipe Card Sort pada taraf kepercayaan $95 \%$.

Tabel 2. Hasil Pengujian Hipotesis Data Hasil Belajar Siswa

\begin{tabular}{lcccc}
\multicolumn{1}{c}{ Kelas } & Nilai Rata-rata & $t_{\text {hitung }}$ & $t_{\text {tabel }}$ & Kesimpulan \\
\hline Index Card Match & 81,04 & 2,496 & 1,98 & Ha diterima \\
Card Sort & 75,81 & & & \\
\hline
\end{tabular}

Kelas Index Card Match secara klasikal sudah dikatakan tuntas karena sudah mencukupi kriteria ketuntasan kelas $\geq 75 \%$ yaitu $79,07 \%$ dan kelas Card Sort secara klasikal belum mencukupi ketuntasan belajar karena hanya 58,14 \% yang tuntas belajar.

Tabel 3. Perbedaan Ketuntasan Belajar Siswa

\begin{tabular}{cccccc}
\hline No & Tingkat & \multicolumn{2}{c}{ Index Card Match } & \multicolumn{2}{c}{ Card Sort } \\
\cline { 3 - 6 } & Ketuntasan & Jumlah Siswa & Persentase & Jumlah Siswa & Persentase \\
\hline 1 & Tuntas & 34 & $79,07 \%$ & 25 & $58,14 \%$ \\
2 & Tidak Tuntas & 9 & $20,93 \%$ & 18 & $41,86 \%$ \\
\hline
\end{tabular}

\section{PEMBAHASAN}

Pembelajaran dengan strategi pembelajaran aktif tipe Index Card Match memiliki persamaan dengan Card Sort, persamaannya terletak pada penggunaan kartu dalam proses pembelajaran, sama-sama mengutamakan kerja tim yang menuntut siswa untuk bekerja sama, selain itu kedua strategi pembelajaran aktif ini mengajak siswa yang lebih aktif sehingga guru hanya bertindak sebagai fasilitator. Karena unsur kesamaan ini peneliti ingin melihat perbedaannya ketika digunakan di kelas yang tingkat kemampuannya sama.

\section{Index Card Match}

Dari hasil penelitian diketahui nilai ratarata hasil belajar siswa di kelas Index Card Match yaitu 81,04. Hasil tersebut dapat dikategorikan tinggi dan sudah melewati batas KKM sebesar 78,00. Kelas Index Card Match secara klasikal sudah mencapai ketuntasan belajar yaitu sebesar $79,07 \%$. Hasil belajar mengalami peningkatan dengan strategi pembelajaran aktif tipe Index Card Match. Hal ini didukung oleh pernyataan Sukmawati (2014) yang menyatakan bahwa terdapat pengaruh yang signifikan pada penggunaan strategi pembelajaran aktif tipe Index Card Match terhadap hasil belajar biologi ranah kognitif.

Menurut Dimyati dan Mudjiono (2013) ketercapaian hasil belajar dipengaruhi oleh faktor dari dalam (internal) dan faktor dari luar (eksternal). Berikut ini faktor internal dan eksternal pada kelas Index Card Match di SMA Negeri 1 Binjai Kabupaten Langkat tahun pembelajaran 2015/2016.

a. Faktor Internal; terdiri dari : (1) Sikap tehadap belajar, siswa di kelas Index Card Match menunjukkan sikap antusias terhadap pelajaran 
dan mereka menerima kesempatan belajar yang diberikan guru dengan baik; (2) Motivasi belajar, siswa di kelas Index Card Match memiliki motivasi belajar yang tinggi terlihat dari kelengkapan bukubuku pelajaran yang dimiliki dan banyaknya siswa yang aktif bertanya dan memberikan pendapat pada saat pembelajaran berlangsung serta siswa sangat semangat dan berlomba-lomba menjawab pertanyaan yang diberikan oleh guru; (3) Konsentrasi belajar, siswa di kelas Index Card Match memiliki konsentrasi belajar yang sangat baik terlihat dari ketenangan siswa saat belajar dan perhatian siswa terpusat pada pelajaran karena siswa memperhatikan dengan baik pada saat guru menjelaskan; (4) Mengolah bahan belajar, siswa di kelas Index Card Match mampu mengolah bahan belajar dengan baik terlihat dari cara mereka yang mampu untuk berdikusi dan mengembangkan pelajaran melalui jawaban-jawaban terhadap permasalahan yang diberikan setelah pembelajaran berlangsung; (5) Menyimpan perolehan hasil belajar, siswa di kelas Index Card Match mampu menyimpan isi pelajaran dengan baik terlihat dari kemampuan mereka dalam menjawab pertanyaan guru mengenai materi pelajaran yang telah lalu; (6) Menggali hasil belajar yang tersimpan, siswa di kelas Index Card Match mampu mengakifkan ingatan tentang materi yang sudah diberikan dan mengaitkannya dengan materi yang baru saja diberikan; (7) Kemampuan berprestasi atau unjuk hasil belajar, siswa di kelas Index Card Match mampu membuktikan keberhasilan belajar terlihat dari nilai rata-rata yang diperoleh sudah mencapai KKM, selain itu dalam melaksanakan strategi siswa juga menunjukkan sikap berpartisipasi dan berlombalomba dalam menyelesaikan langkah-langkah yang diberikan; (8) Rasa percaya diri, siswa di kelas Index Card Match memiliki rasa percaya diri yang tinggi dan mereka sangat berani dalam bertanya, menjawab dan mengemukakan pendapat; (9) Intelegensi, siswa di kelas Index Card Match mampu berpikir secara baik dan bergaul dengan lingkungan secara efisien, pada saat jam istirahat sebagian siswa memilih untuk duduk di dalam kelas sambil membaca buku pelajaran atau sedikit berdikusi dengan temannya tentang pelajaran yang baru saja diberikan; (10) Kebiasaan belajar, siswa di kelas Index Card Match sangat disiplin dalam belajar, mereka selalu hadir tepat waktu, tidak ada siswa yang terlambat dan semuanya berkelakuan baik.

b. Faktor eksternal; terdiri dari : (1) Guru sebagai pembina siswa belajar, guru sudah mampu menguasai kelas dan memusatkan perhatian siswa untuk membangkitkan semangat belajar dengan cara menggunakan strategi pembelajaran yang bervariasi; (2) Prasarana dan sarana pembelajaran di SMA Negeri 1 Binjai Kabupaten Langkat sudah lengkap dan layak untuk digunakan agar menunjang proses pembelajaran; (3) Lingkungan sekolah yang tenang, jauh dari jalan utama sehingga terhindar dari keramaian dan suara-suara kendaraan yang melintas sehingga baik untuk proses pembelajaran siswa.

Faktor internal dan eksternal tersebut sangat memengaruhi hasil belajar siswa. Pada penelitian ini keberhasilan pembelajaran dibuktikan dengan menggunakan strategi pembelajaran yang merupakan salah satu faktor dari luar (eksternal). Strategi pembelajaran merupakan salah satu aspek penting yang memengaruhi hasil belajar siswa. Jika strategi pembelajaran yang digunakan dalam mengajar suatu materi pembelajaran itu tepat, maka hasil belajar siswa juga cenderung lebih baik dan begitupula sebaliknya. Penggunaan strategi pembelajaran aktif tipe Index Card Match ini sebenarnya tidak terbatas dalam materi apapun karena strategi ini bertujuan untuk melibatkan siswa secara aktif dalam proses pembelajaran. Namun, strategi ini sangat cocok diterapkan pada materi sistem ekskresi karena materi sistem ekskresi adalah salah satu materi yang cukup sulit dan membosankan bila dipelajari dengan metode konvensional sehingga perlu diajarkan dengan strategi pembelajaran yang memberikan efek menyenangkan dan membuat siswa tertantang dengan unsur permainan yang ada di dalamnya.

Menurut Amrayeti dkk. (2011) strategi Index Card Match (ICM) mengajarkan pada siswa untuk lebih berani ke depan kelas untuk menerangkan apa yang mereka peroleh dalam pembelajaran, saling berbagi pengetahuan tentang materi yang dipelajari dan dapat saling bekerja sama diantara pasangan kelompok dalam 
memahami materi pelajaran. Berdasarkan hasil penelitian, penerapan strategi Index Card Match pada materi sistem ekskresi manusia, mampu melatih siswa untuk teliti dan jujur dalam mengembangkan konsep materi sistem ekskresi manusia yang telah dipelajari sehingga hasil pencarian kartu indeks yang diperoleh benar. Tanggung jawab mempunyai peranan penting agar pencarian kartu indeks dapat berjalan dengan baik. Siswa dapat membagi tugas pencarian kartu indeks dengan baik serta disiplin sehingga materi sistem ekskresi manusia dapat disampaikan tepat waktu sesuai dengan rencana pembelajaran yang telah dibuat oleh guru. Setiap siswa dilatih untuk bekerja sama dalam mendiskusikan hasil pencarian pasangan kartu yang sudah dicocokkan oleh siswa bersama pasangannya.

Pelaksanaan strategi Index Card Match pada kelas eksperimen I terkendala oleh adanya keterbatasan waktu sehingga materi sistem ekskresi manusia belum terkonfirmasi atau review secara lengkap atau menyeluruh, tetapi masih mampu meningkatkan pemahaman siswa terhadap materi sistem ekskresi manusia. Hal tersebut menyebabkan tidak semua siswa mendapat nilai mencapai KKM.

\section{Card Sort}

Dari hasil penelitian diketahui nilai ratarata hasil belajar siswa di kelas Card Sort yaitu 75,81 . Hasil tersebut dapat dikategorikan sedang dan belum melewati batas KKM sebesar 78,00. Kelas Card Sort secara klasikal belum mencapai ketuntasan belajar yaitu hanya sebesar $58,14 \%$. Meskipun begitu, hasil belajar biologi siswa tetap mengalami peningkatan dengan strategi pembelajaran aktif tipe Card Sort. Hal tersebut didukung oleh penelitian Mufidah dkk. (2013) yang menunjukkan bahwa dengan menerapkan strategi pembelajaran Card Sort dapat meningkatkan hasil belajar IPA tentang Cahaya dan Sifat-sifatnya.

Berikut ini faktor internal dan eksternal pada kelas Card Sort di SMA Negeri 1 Binjai Kabupaten Langkat tahun pembelajaran 2015/2016. a. Faktor Internal; terdiri dari : (1) Sikap tehadap belajar, siswa di kelas Card Sort menunjukkan sikap antusias terhadap pelajaran dan mereka menerima kesempatan belajar yang diberikan guru dengan baik; (2) Motivasi belajar, siswa di kelas Card Sort memiliki motivasi belajar yang kurang tinggi terlihat dari adanya siswa yang lupa membawa buku pelajaran meskipun mereka sudah punya dan sedikit siswa yang aktif bertanya dan memberikan pendapat pada saat pembelajaran berlangsung namun siswa semangat menjawab pertanyaan yang diberikan oleh guru; (3) Konsentrasi belajar, siswa di kelas Card Sort memiliki konsentrasi belajar yang kurang baik karena tidak semua siswa memperhatikan pada saat guru menjelaskan; (4) Mengolah bahan belajar, siswa di kelas Card Sort mampu mengolah bahan belajar dengan baik terlihat dari cara mereka yang mampu untuk berdikusi dan mengembangkan pelajaran melalui jawabanjawaban terhadap permasalahan yang diberikan setelah pembelajaran berlangsung; (5) Menyimpan perolehan hasil belajar, siswa di kelas Card Sort mampu menyimpan isi pelajaran dengan baik terlihat dari kemampuan mereka dalam menjawab pertanyaan guru mengenai materi pelajaran yang telah Ialu; (6) Menggali hasil belajar yang tersimpan, siswa di kelas Card Sort kurang mampu mengakifkan ingatan tentang materi yang sudah diberikan dan mengaitkannya dengan materi yang baru saja diberikan; (7) Kemampuan berprestasi atau unjuk hasil belajar, siswa di kelas Card Sort belum mampu membuktikan keberhasilan belajar terlihat dari nilai rata-rata yang diperoleh belum mencapai KKM, namun dalam melaksanakan strategi siswa menunjukkan sikap berpartisipasi dan berlomba-lomba dalam menyelesaikan langkah-langkah yang diberikan; (8) Rasa percaya diri, siswa di kelas Card Sort memiliki rasa percaya diri yang kurang tinggi sehingga mereka takut untuk bertanya, menjawab dan mengemukakan pendapat; (9) Intelegensi, siswa di kelas Card Sort mampu berpikir secara baik dan bergaul dengan lingkungan secara efisien; (10) Kebiasaan belajar, siswa di kelas Index Card Match kurang disiplin dalam belajar, ada siswa yang terlambat sehingga mengganggu konsentrasi siswa yang lain dan ada beberapa siswa yang sering menimbulkan keributan karena celotehan-celotehan tidak penting yang ditanggapi oleh siswa lainnya sehingga membuyarkan pusat perhatian siswa.

b. Faktor eksternal; terdiri dari : (1) Guru sebagai pembina siswa belajar, guru sudah mampu 
menguasai kelas dan memusatkan perhatian siswa untuk membangkitkan semangat belajar dengan cara menggunakan strategi pembelajaran yang bervariasi; (2) Prasarana dan sarana pembelajaran di SMA Negeri 1 Binjai Kabupaten Langkat sudah lengkap dan layak untuk digunakan agar menunjang proses pembelajaran; (3) Lingkungan sekolah yang tenang, jauh dari jalan utama sehingga terhindar dari keramaian dan suara-suara kendaraan yang melintas sehingga baik untuk proses pembelajaran siswa.

Faktor internal dan eksternal tersebut sangat memengaruhi hasil belajar siswa. Faktor eksternal yang paling mencolok adalah penggunaan strategi pembelajaran. Penggunaan strategi pembelajaran aktif tipe Card Sort ini tidak terbatas dalam materi apapun karena strategi ini bertujuan untuk melibatkan siswa secara aktif dalam proses pembelajaran. Strategi ini juga cocok diterapkan pada materi sistem ekskresi karena materi sistem ekskresi adalah salah satu materi yang cukup sulit dan membosankan bila dipelajari dengan metode konvensional sehingga perlu diajarkan dengan strategi pembelajaran yang memberikan efek menyenangkan dan membuat siswa tertantang dengan unsur permainan yang ada di dalamnya. Namun, faktor yang menyebabkan nilai hasil belajar di kelas Card Sort belum mencapai KKM adalah penempatan strategi ini kurang sesuai dengan karakteristik atau faktor eksternal dan internal kelas maupun anak. Strategi pembelajaran aktif ini menuntut siswa untuk belajar lebih aktif, meningkatkan daya kritis siswa, meningkatkan kerja sama antara siswa karena mereka harus berusaha untuk menemukan kelompok yang sesuai dalam waktu yang cukup singkat. Sedangkan siswa di dalam kelas kurang mampu memenuhi tuntutan strategi pembelajaran aktif tersebut. Hal ini didukung oleh penelitian Mufidah dkk. (2013) yang menyatakan bahwa masih ada beberapa siswa yang mengalami kesulitan dalam memahami materi dikarenakan ada beberapa siswa yang tidak memperhatikan ketika guru menjelaskan dan kurang aktif mengikuti permainan kartu yang telah disediakan guru. Mereka hanya ikut-ikutan temannya dalam menempelkan kartu tanpa memahami isi materi yang ada dalam kartu tersebut. Selain itu, kelemahan dari strategi pembelajaran ini yaitu adanya kemungkinan terjadi penyimpangan perhatian siswa dalam proses pembelajaran, terutama apabila terjadi jawaban-jawaban yang menarik perhatiannya padahal bukan sasaran (tujuan) yang diinginkan, dalam arti terjadi penyimpangan dari pokok persoalan semula. Akibatnya kelas menjadi gaduh disebabkan oleh persoalan-persoalan yang bukan menjadi pokok pembahasan. Hal tersebut tentu saja berpengaruh pada hasil belajar yang diperoleh. Strategi pembelajaran aktif tipe Card Sort ini baik diterapkan pada materi ekskresi jika faktor internal dan eksternal siswa mendukung untuk dilakukan strategi ini.

\section{Perbandingan strategi Index Card Match dengan Card Sort}

Berdasarkan hasil uji hipotesis diketahui bahwa ada perbedaan antara hasil belajar siswa yang diajar menggunakan strategi pembelajaran aktif tipe Index Card Match dengan Card Sort pada materi sistem ekskresi manusia di kelas XI IPA SMA Negeri 1 Binjai Kabupaten Langkat tahun pembelajaran 2015/2016. Analisis data penelitian menunjukkan bahwa hasil belajar siswa dengan menggunakan strategi pembelajaran aktif tipe Index Card Match berbeda secara secara signifikan dan lebih tinggi dibandingkan dengan strategi pembelajaran aktif tipe Card Sort. Hal ini sejalan dengan pernyataan Haryanto (2011) bahwa kelas perlakuan Index Card Match mendapat nilai ratarata sebesar 74, 073 lebih tinggi dibandingkan dengan kelas Card Sort yang mendapat nilai ratarata 69,756. Kemudian Amrayeti dkk. (2011) menunjukkan bahwa siswa yang diberikan perlakuan Index card match memperoleh rata-rata sebesar 78,40. Sementara itu Sutarti (2013) menemukan bahwa nilai rata-rata tes awal yang hanya 57,81 , setelah diajar dengan menggunakan Card Sort pada siklus I meningkat menjadi 63,12 dan siklus II meningkat menjadi 72,12 , hasil tersebut masih lebih rendah bila dibandingkan dengan penelitian Amrayeti dkk. (2011).

Berdasarkan perhitungan PPH (persentase pencapaian hasil) diketahui bahwa pada kelas yang diajar dengan strategi pembelajaran aktif tipe Index Card Match sebanyak 34 dari 43 siswa atau sebesar 79,07\% 
mengalami ketuntasan sedangkan pada kelas yang diajar dengan strategi pembelajaran aktif tipe Card Sort sebanyak 25 dari 43 siswa atau sebesar $58,14 \%$ mengalami ketuntasan belajar dengan nilai diatas 78,00. Hal tersebut menunjukkan bahwa kelas Index Card Match secara klasikal sudah mencapai ketuntasan belajar sedangkan kelas Card Sort belum mencapai ketuntasan belajar.

Berdasarkan pernyataan-pernyataan yang mendukung di atas dan yang dilakukan oleh peneliti diketahui bahwa pembelajaran dengan strategi pembelajaran aktif tipe Index Card Match lebih baik dibandingkan dengan Card Sort pada materi sistem ekskresi manusia di kelas XI IPA SMA Negeri 1 Binjai Kabupaten Langkat tahun pembelajaran 2015/2016. Hal ini disebabkan karena penerapan strategi Index Card Match di kelas Eksperimen I pada materi sistem ekskresi manusia mampu mengembangkan karakter serta keterampilan sosial. Berdasarkan wawancara peneliti dengan beberapa siswa, siswa di kelas tersebut sangat menyukai belajar sambil bermain dan tidak terlalu monoton ataupun serius. Hal ini tentu saja berpengaruh terhadap hasil belajar siswa yang memang lebih tinggi dibandingkan kelas Eksperimen II yang diajar menggunakan strategi Card Sort. Seperti pendapat Hamdani (2011) strategi belajar dapat menuntut keaktifan serta partisipasi siswa dalam setiap kegiatan belajar seoptimal mungkin sehingga siswa mampu mengubah tingkah lakunya secara efektif dan efisien.

Dari hasil penelitian terlihat bahwa strategi pembelajaran aktif tipe Index Card Match dan Card Sort sama-sama meningkatkan hasil belajar siswa. Perbedaan peningkatan hasil belajar tersebut terlihat pada perolehan nilai belajar siswa pada kedua kelas penelitian. Jadi dapat dikatakan bahwa strategi pembelajaran aktif tipe Index Card Match lebih baik digunakan untuk meningkatkan hasil belajar siswa pada materi sistem ekskresi manusia di kelas XI IPA SMA Negeri 1 Binjai Kabupaten Langkat tahun pembelajaran 2015/2016.. Penggunaan strategi pembelajaran aktif tipe Index Card Match membuat siswa lebih aktif dalam belajar karena dengan strategi ini siswa dituntut untuk lebih memahami materi dengan cara memahami penjelasan guru, membaca materi di buku agar menang dan tercepat dalam permainan yang diberikan oleh guru. Dengan cara ini siswa yang biasanya duduk diam dan kurang aktif dikelas juga lebih termotivasi untuk mempelajari materi yang tidak dimengerti dan menjadi lebih aktif lagi.

\section{SIMPULAN}

Berdasarkan penelitian yang telah dilakukan maka dapat disimpulkan yakni: 1). Hasil belajar siswa yang diajar menggunakan strategi pembelajaran aktif tipe Index Card Match pada materi sistem ekskresi manusia di kelas XI IPA SMA Negeri 1 Binjai Kabupaten Langkat tahun pembelajaran 2015/2016 adalah $81,04 \pm 9,42$. 2). Hasil belajar siswa yang diajar menggunakan strategi pembelajaran aktif tipe Card Sort pada materi sistem ekskresi manusia di kelas XI IPA SMA Negeri 1 Binjai Kabupaten Langkat tahun pembelajaran 2015/2016 adalah 75,81 $\pm 9,99$. 3). Hasil belajar siswa yang diajar menggunakan strategi pembelajaran aktif tipe Index Card Match pada materi sistem ekskresi manusia di kelas XI IPA SMA Negeri 1 Binjai Kabupaten Langkat tahun pembelajaran 2015/2016 lebih tinggi dibandingkan dengan Card Sort dan berbeda secara signifikan pada $\alpha=0,05$ sehingga strategi Index Card Match lebih baik digunakan pada materi dan kelas tersebut.

\section{DAFTAR PUSTAKA}

Achmad I, Sariwulan D, dan Ana RW. 2014. Penerapan Learning Class untuk Mendiagnostik Kesulitan Belajar Siswa SMA pada Materi Sistem Ekskresi Manusia. Jurnal Fomica Education Online. 1(1): 2.

Amrayeti D, Rahmi, Fitri, DY. 2011. Pengaruh Penerapan Metode Index Card Match (ICM) terhadap Pemahaman Konsep Matematis Siswa Kelas VIII MTsN Pekan Selasa Kabupaten Solok Selatan [Skripsi]. Sumatera Barat: STKIP PGRI SUMBAR.

Dimyati dan Mudjiono. 2013. Belajar dan Pembelajaran. Jakarta: Rineka Cipta.

Hamdani. 2011. Strategi Belajar Mengajar. Bandung: Pustaka Setia.

Haryanto. 2011. Pengaruh Strategi Pembelajaran Aktif Card Sort dan Index Card Match terhadap Prestasi Belajar Getaran Dan 
Halaman : $133-142$

Gelombang di Kelas VII MTs. Futuhiyyah 1 Mrangen Demak Tahun Ajaran 2010/2011 [Skripsi]. Semarang: Universitas Negeri Semarang.

Marjan J, Arnyana BP, dan Setiawan N. 2014. Pengaruh Pembelajaran Pendekatan Saintifik Terhadap Hasil Belajar Biologi dan Ketrampilan Proses Sains Siswa MA Mu'alimat NW Pancor Selong Kabupaten Lombok Nusa Tengara Barat. e-journal Program Pascasarjana Universitas Pendidikan Ganesha. 4(4): 4.

Mufidah AU, Hadi M, Sularmi. 2013. Penerapan Strategi Pembelajaran Card Sort untuk Meningkatkan Hasil Belajar IPA Tentang Cahaya dan Sifat-Sifatnya, Jurnal Pendidikan Universitas Sebelas Maret, Surakarta.

Sudjana. 2002. Metode Statistika. Bandung: Tarsito.

Sukmawati, D. 2014. Pengaruh Penggunaan Strategi Pembelajaran Aktif Tipe Index Card Match Terhadap Hasil Belajar Biologi pada Materi Jaringan Hewan di Kelas XI IPA SMA Negeri 8 Muaro Jambi [Skripsi]. Jambi: Universitas Jambi.

Usman U. 2005. Menjadi Guru Profesional. Bandung: Remaja Rosda Karya. 